\title{
Historia komunizmu splątana między państwami: nowe perspektywy badań w Europie Środkowo-Wschodniej
}

Brzechczyn Krzysztof, red. New Perspectives in Transnational History of Communism in East Central Europe. Bern: Peter Lang Verlag, 2019. $386 \mathrm{s.}$ Seria wydawnicza Dia-Logos. Studies in Philosophy and Social Sciences ukazuje się od 2002 roku i zdążyła wyrobić sobie silną pozycję nie tylko na arenie krajowej, ale i międzynarodowej. Jest to zasługą konsekwentnie realizowanego programu przez redaktorów serii: Tadeusza Buksińskiego i Piotra W. Juchacza, którzy starają się nie tylko zintegrować zaangażowaną filozofię i nowoczesne nauki społeczne, ale również włączyć środkowo-europejskie głosy do światowej dyskusji. Obie inicjatywy są godne wspierania, lecz o sukcesie wspominanej serii świadczy nie tylko dobór i aktualność tematów, ale przede wszystkim wysoka jakość merytoryczna publikacji.

Już na wstępie mogę stwierdzić, że opublikowana w 2019 roku kolejna, dwudziesta szósta już, pozycja w wspomnianej serii wydawnictwa Peter Lang wpisuje się bardzo dobrze w jej ambitne założenia i wysokie standardy. New Perspectives in Transnational History of Communism in East Central Europe pod redakcją profesora Krzysztofa Brzechczyna (Wydział Filozoficzny UAM oraz Oddziałowe Biuro Badań Historycznych IPN w Poznaniu) jest nie tylko efektem obserwowanego renesansu badań nad totalitaryzmami $\mathrm{xx}$ wieku 
w Europie Środkowo-W schodniej, ale również próbą zmierzenia się z nowymi propozycjami teoretycznymi, które napływają z różnych dziedzin ${ }^{1}$.

Niniejszy tekst złożony jest z dwóch części: w pierwszej przedstawione zostaną najważniejsze założenia teoretyczne, które stanowiły motywację do zwołania konferencji oraz powstania publikacji. W części drugiej omówione zostaną pokrótce poszczególne artykuły naukowe tworzące New Perspectives. Przez cały czas zachowane zostanie podejście krytyczne, które nie ma na celu merytorycznej polemiki z treścią książki, a jedynie określenie innowacyjności proponowanego podejścia teoretycznego oraz stopnia jego praktycznej realizacji.

\section{Postulaty teoretyczne}

Przede wszystkim należy powiedzieć, że sam tytuł omawianej książki jest obietnicą wprowadzenia nowych perspektyw do historiografii europejskiego komunizmu. Jest to ambitne zadanie, szczególnie w odniesieniu do tak dobrze ugruntowanej sfery badań. Pomimo istnienia bogatej literatury tematu, jest dla mnie oczywiste, że wciąż zbyt mało jest badań wykraczających poza perspektywę stricte narodową. Już od dawna postulowano, że zjawisko takie jak komunizm niejako $\mathrm{z}$ definicji nie powinno być zamknięte w granicach jednej historiografii, lecz powinno być rozpatrywane globalnie i komparatystycznie (Tucker 242). Ta teza pozostaje aktualna do dziś.

Dokładnie taką perspektywę zarysował w swoim wprowadzeniu redaktor tomu, zwracając dodatkowo uwagę na dynamiczny rozwój badań transnarodowych ${ }^{2}$. Oddziela on je wyraźną kreską od badań komparatystycznych,

1 Świadczy o tym chociażby szkoła letnia pt. "Remembering Communism" (Summer School of Interdisciplinary Polish and German Studies) zorganizowana we Frankfurcie nad Odrą w 2017 roku; konferencja "Totalitarian reverberations in East-Central Europe”, 26-28.10.2018, Faculty of European Studies, Cluj-Napoca oraz wydanie w Polsce tłumaczenia kluczowej pozycji pod redakcją Carla J. Friedricha Totalitaryzm. Materiały z konferencji zorganizowanej przez Amerykańska Akademię Sztuk i Nauk w marcu 1953 roku (zob. Friedrich).

2 W języku polskim czasem tłumaczy się przymiotnik transnational jako 'ponadnarodowy’ (np. podczas konferencji w Wrocławiu z 2011 pt. „Czy jest możliwa historia ponadnarodowa? Wokół nowej syntezy dziejów niemiecko-polskich”), wydaje się jednak, że nie należy traktować historii ponadnarodowej jako synonimu, transnational history/ entangled history czy histoire croisée, gdyż odpowiednikiem ponadnarodowości jest raczej angielskie słowo supranational. W związku z tym postaram się konsekwentnie tłumaczyć transnational history jako historię transnarodową, podkreślając tym neologizmem element „Związania” i „przenikania”. Wydaje się to tym bardziej uzasadnio- 
przekonująco argumentując, iż wynikają one z różnych przesłanek. Podejście komparatystyczne przyjmuje funkcjonujące historiografie narodowe jako gotowe, niezależne byty i dokonuje ich porównania poprzez wtórne wyznaczenie kryteriów do ich oceny. Taka koncepcja może być rozwijana na dostępnym materiale i w tym sensie nie stanowi całkiem nowej perspektywy, lecz umożliwia niejako uporządkowanie i kontekstualizację istniejących opisów (Brzechczyn 15).

Podejście transnarodowe jest, zdaniem Brzechczyna, w swoich założeniach dużo trudniejsze. Opiera się ono na pierwotnym „zapomnieniu” o istnieniu granic i różnic narodowych, aby umożliwić spojrzenie na fenomen komunizmu jako ruchu globalnego. Porównanie tak skonstruowanego modelu z jego konkretną realizacją stanowi kolejny krok badania. W takim ujęciu kontekst narodowy nie stanowi punktu wyjścia analizy, przeciwnie, to perspektywa globalnego ruchu umożliwia zdefiniowanie i zrozumienie lokalnego (narodowego) kontekstu. Z drugiej strony podkreśla się czasem, że istnienie historiografii narodowych jest warunkiem sine qua non powstania historiografii transnarodowych (Kocka, Haupt 6). Brzechczyn odwraca ten porządek metodologiczny, twierdząc, że bez transnarodowego spojrzenia poszczególne historie narodowe są niezrozumiałe (Brzechczyn 16). Takie ambitne odwrócenie strategii poznawczej może faktycznie rościć sobie pretensje do ambitnego określenia „nowe perspektywy”.

Należy jednak stwierdzić, że jest ono tyleż teoretycznie fascynujące, co praktycznie skomplikowane. Nie jest łatwo „odłożyć na bok” kontekst, w którym badacze się wychowali, kształcili i pracują. Czy można wyzwolić się ze swojej partykularnej historii? Przeglądając noty biograficzne autorów, należy zauważyć,

ne, że taką konwencję przyjął również redaktor tomu w polskiej wersji książki: Nowe perspektywy badawcze $w$ transnarodowej historii komunizmu $w$ Europie Środkowo-Wschodniej (red. naukowa Krzysztof Brzechczyn). W polskiej wersji brak jest tekstu Jakuba Muchowskiego lecz są za to dwa nowe artykuły: Zsófii Lóránd, Idee nowego feminizmu: stawianie państwu wyzwań czy udoskonalanie jugosłowiańskiego socjalizmu? i Branislava Radeljića Stosunki między Wspólnotą Europejską a Jugosławią: dokumenty, które mialy znaczenie (1980-1992).

Warto zauważyć, że ten termin został również użyty na seminarium i konferencji zorganizowanej przez Wydział Historyczny CEU (Constantin Iordachi i inni) w 2010 roku w odniesieniu do badań porównawczych „Comparative Studies of Communism: New Perspectives” (27-29.05.2010, Budapeszt). Wcześniej pojawił się również w książce redagowanej przez Kocką i Haupta z 2009 roku (zob. Kocka, Haupt). Wydaje się, że Brzechczyn świadomie sięga do funkcjonującej terminologii, pragnąc włączyć się w toczącą się w Niemczech i na Węgrzech dyskusję. Dziwi jednak, że choć wprost odwołuje się do węgierskich badaczy, to pozycja niemieckich historyków pojawia się w recenzowanej książce tylko raz, w artykule Christie Miedemy (241). 
że wielu z nich żyło i pracowało w więcej niż jednym państwie europejskim. Ten kosmopolityzm, historycznie charakterystyczny dla Europy Środkowo-Wschodniej, tłumaczy możliwość sensownej realizacji przedsięwzięcia. Obserwujemy obecnie moment, gdy pokolenie, które nie zostało już ukształtowane przez doświadczenia komunizmu, podejmuje się jego teoretycznej reinterpretacji. Poszukiwanie nowych perspektyw wydaje się uzasadnione w czasie, gdy do głosu dochodzą przedstawiciele młodszego pokolenia, które funkcjonuje w kontekście transnarodowym, dostępnym na szerszą skalę po upadku komunizmu i włączeniu Młodszej Europy w struktury, również akademickie, państw Unii Europejskiej. Oczywiście to zjawisko występowało już wcześniej, nie miało jednak charakteru masowego oraz wsparcia instytucjonalnego na poziomie narodowym i ponadnarodowym. Włączenie się uznanych badaczy w dyskusje nad nowymi prądami w historiografii otwiera potencjalnie drogę do dialogu między generacjami w różny sposób doświadczonymi historią komunizmu europejskiego.

Mimo pojawienia się nowych możliwości społecznych i technologicznych wiele transnarodowych narracji nie potrafi zrealizować swojego ambitnego programu i po górnolotnych założeniach teoretycznych proponuje lepiej lub gorzej skrojoną kompilację historii narodowych, starając się ewentualnie dać w nich więcej miejsca „mniejszym” narodom. Dekonstrukcja europocentryzmu czy uznanie roszczeń historii postkolonialnych nie oznacza automatycznie zaprezentowania nowego modelu opisywania i wyjaśniania w historiografii, którego priorytetem będzie postulowanie metodologicznego „przełamywania granic”. Podejście „transnarodowe” czerpie część motywacji z teorii „badań postkolonialnych", metodologicznie odnosząc się jednak do historii globalnej i porównawczej. Punktem wspólnym jest tutaj krytyka dominującej i ekspansywnej polityki kulturowej państw narodowych.

Brzechczyn słusznie zauważa we wprowadzeniu, że oparcie historiografii o państwo narodowe było paradygmatem przyjętym powszechnie w tworzonej w XIx Europie historiografii naukowej (Brzechczyn 15). W mniej lub bardziej zamaskowanej formie paradygmat „historiografii narodowej” przetrwał przez cały wiek xx, okazując się jednym z najbardziej trwałych założeń wszelkich narracji o rzeczywistości minionej. Redaktor tomu uznaje taką sytuację za naturalną konsekwencję powstawania państw narodowych, ale również za konstrukt polityki kulturowej tych państw.

Omawiana książka wpisuje się w swoistą modę na badania transnarodowe, które zdobywają popularność od początku xxi wieku. Brzechczyn zauważa jednak, że zwiększonej popularności nie odpowiada osiągnięcie klarownego stanowiska teoretycznego w podejmowaniu tych zagadnień. Doprowadziło to do nadużywania etykiety transnarodowości w miejscach, gdzie w istocie 
chodziło o historię porównawczą, międzynarodową lub globalną. Pytanie, czy $\mathrm{w}$ istocie mamy do czynienia jedynie z problemem terminologicznym, czy z faktycznym zamieszaniem metodologicznym, nieprzerwanie przyciąga uwagę badaczy (Iriye 9).

Redaktor tomu proponuje, aby z tej sytuacji wyciągnąć wniosek: odpowiednie zdefiniowanie tego, czym jest historia transnarodowa, stało się problemem metodologicznym oraz problemem badawczym. Aby poprzeć tą konstatację, powołuje się na dyskusję pomiędzy historykami amerykańskimi (AHR 1442). Kluczem do rozwiązania powstałych niejasności teoretycznych jest dla niego jasne oddzielnej historii transnarodowej od historii porównawczej (Brzechczyn 16). Taka perspektywa zostaje przez niego racjonalnie wyjaśniona w dalszej części wprowadzenia.

Brzechczyn wzorowo wskazuje na przyczyny popularności historiografii transnarodowej, skupiając się z jednej strony na nowych pokoleniach badaczy, z drugiej na technicznych możliwościach oferowanych przez Internet (komunikacja między badaczami oraz dostęp do digitalizowanych źródeł). Tłumaczyć to ma również, dlaczego historiografia transnarodowa nie była wcześniej możliwa. Następnie podaje Brzechczyn za Peterem Aporem i Constantinem Iordachim trzy główne płaszczyzny badań transnarodowych: (1) totalitaryzacja i detotalitaryzacja, (2) teorie modernizacji oraz (3) historia codzienności (Apor, Iordachi 11). Zdaniem autora to właśnie koncepcje modernizacji (2) jako pierwsze metanarracje zaczęły rozważać możliwość transnarodowej interpretacji komunizmu w Europie wschodniej, zauważając, że miał on tam charakter inny niż na zachodzie kontynentu (Brzechczyn 17).

Brzechczyn nie ukrywa, że przejmuje wiele poglądów Apora i Iordachiego, jednocześnie podejmując polemikę metodologiczną z ich podejściem. Wspomniani autorzy nie widzą potrzeby ostrego rozgraniczenia między podejściem komparatystycznym a transnarodowym i zdają się dążyć do wzbogacenia pierwszego przez drugie ${ }^{4}$. Badania transnarodowe mają poszerzyć i kontynuować założenia porównawczej historii komunizmu, a nie rywalizować z nimi, gdyż w istocie wspólnym celem pozostaje kompleksowe wyjaśnienie tego złożonego zjawiska. Większość badaczy dostrzega pewne „napięcia” między tymi dwoma podejściami, jednak podkreśla również cechy wspólne (Kocka 44).

4 W tę stronę wydaje się również podążać łączona antologia porównawczej i transnarodowej historii Europy Środkowo-Wschodniej planowana na 3 tomy: The Rise of Comparative History. Perspectives on Comparative and Transnational History in East Central Europe and Beyond. A Reader (red. B. Trencsenyi, C. Iordachi, P. Apor) (już w pierwszym tomie znajdą się tłumaczenia ważnych tekstów polskich historyków: Jana Rutkowskiego, Marcelego Handelsmana i Oskara Halickiego). 
W odróżnieniu od tych autorów Brzechczyn wskazuje na fundamentalne różnice w metodologicznych założeniach między podejściem transnarodowym i komparatystycznym. To drugie ma swoją ugruntowaną pozycję co najmniej od czasu Marca Blocha, jednak niewątpliwie przeżywa obecnie renesans, szczególnie w badaniach nad komunizmem. Wzrost popularności częściowo wywołany jest właśnie przez włączenie nowatorskich strategii badań trans- i ponadnarodowych. Brzechczyn przekonująco argumentuje, że w istocie mamy tutaj do czynienia $z$ dwoma różnymi podejściami, które należy od siebie oddzielić. Z drugiej strony podawany przez niego przykład sekularyzacji społeczeństw europejskich nie stoi bynajmniej w sprzeczności z założeniami historii porównawczej (Brzechczyn 18). Można ostatecznie stwierdzić, że krótkie wprowadzenie redaktora sygnalizuje kilka interesujących problemów na styku historii komparatystycznej i transnarodowej, ale ich nie rozwiązuje.

Pełna realizacja tak zarysowanych założeń historii transnarodowej pozostaje niespełnioną obietnicą recenzowanego tomu, jednocześnie wskazując na konieczność kontynuacji prac w tym kierunku. Omawiana książka została podzielona na pięć rozdziałów, niestety zabrakło szerszego wyjaśnienia, dlaczego takie, a nie inne zakresy tematyczne zostały wyróżnione. Zapewne decydowały po prostu zainteresowania poszczególnych autorów oraz ich interpretacja skomplikowanej i niejednoznacznej metodologii badań transnarodowych. Poszczególne rozdziały, choć bardzo dobrze ułożone, nie stanowią koherentnie zamkniętych całości, a jedynie próbę ukazania przydatności badań transnarodowych dla wyjaśnienia konkretnych aspektów komunizmu.

Dzieje się tak dlatego, że mimo stylistycznej konsekwencji w używaniu słowa „rozdział” dla poszczególnych tekstów stanowią one rozwiniecie referatów z konferencji z 2014 roku (International Conference „New Perspectives in the Transnational History of Communism in East-Central Europe”, 16-17.10.2014, Poznań). Są to w istocie samoistne artykuły naukowe, napisane przez bardzo zróżnicowane grono autorów interpretujących na swój sposób Call for Papers Brzechczyna. Z jednej strony w ten sposób zachowana jest konsekwentnie interdyscyplinarna i transnarodowa perspektywa, z drugiej uzyskane to zostało kosztem spójności publikacji, co jest typową cechą materiałów pokonferencyjnych. Na plus zaliczyć trzeba jeszcze niezwykle przekrojową reprezentację większości narodowych historiografii europejskich krajów demokracji ludowej. Całość jest również zróżnicowana tematycznie i przedstawia wiele z postulowanych „nowych perspektyw”.

Brzechczyn wskazuje na trzy sposoby, na które manifestuje się transnarodowość w badaniach autorów tomu: (1) analizując użyteczność teorii i modeli charakterystycznych dla badań transnarodowych; (2) przeprowadzając bada- 
nia z wykorzystaniem tych metod; (3) przeprowadzając badania za pomoca kategorii uniwersalnych, które mogą być stosowane z powodzeniem do wielu społeczeństw (Brzechczyn 18). Jak łatwo zauważyć, punkt trzeci przynależy do perspektywy komparatystycznej i to właśnie ona wydaje się wyznaczać dominujący ton w wielu fragmentach książki, pokazując, jak trudne z punktu widzenia praktyki badawczej jest realizowanie postulowanego ostrego rozdziału między badaniami porównawczymi a transnarodowymi. Nie przekreśla to jednak metodologicznej wagi zauważonego przez redaktora problemu.

Być może założenia Brzechczyna są na dzień dzisiejszy po prostu zbyt ambitne lub możliwe jedynie w formie bardziej koherentnego projektu niż międzynarodowa konferencja. Pomimo uznania specyficznych uwarunkowań publikacji pokonferencyjnych wydaje się uzasadnione ocenienie tej książki i poszczególnych artykułów właśnie z perspektywy realizacji podjętego przedsięwzięcia, jakim jest transnarodowa interpretacja europejskiego komunizmu. Dzieje się tak dlatego, że najważniejszym „efektem” tej publikacji jest ukazanie trudności teoretycznych oraz praktycznych związanych z transnarodowością $\mathrm{w}$ badaniach nad komunizmem.

\section{Praktyczne realizacje}

New Perspectives składa się z pięciu części. Pierwsze trzy dzielą opisywany przedmiot ogólny - komunizm - na mniejsze wymiary: I) Polityczny, II) Ideologiczny, III) Ekonomiczno-społeczny; podczas gdy ostatnie dwie nazwane zostały odpowiednio: IV) Państwa i społeczeństwa Europy Środkowo-Wschodniej z perspektywy transnarodowej oraz v) Pamięć i narracje o środkowo-wschodnim komunizmie. Na początku znajdują się noty biograficzne oraz wprowadzenie redaktora, który również streszcza bardzo krótko poszczególne artykuły. Poszczególne teksty kończą się wskazaniem bibliografii, a na końcu książki znajduje się indeks osobowy.

Wszystkie teksty stoją na wysokim poziomie, jednak wydaje się, że nie wszyscy autorzy podzielają zaprezentowaną przez redaktora wizję perspektywy transnarodowej lub nie dostrzegają jej konfliktu z podejściem porównawczym w praktyce. Większość skupia się na tradycyjnych opisach podkreślających specyfikę historyczną konkretnego państwa narodowego. W pozostałych tekstach przyjęto metodę porównawczą, realizując ją z powodzeniem. Transnarodowość metod i tematów badań pozostaje niewątpliwie w tle, widać jednak, że na razie stanowi ona raczej ciekawą i perspektywiczną ideę niż konkretny program badań.

Brzechczyn w artykule otwierającym właściwą treść książki (i jej pierwszy „rozdział”) przeprowadza analizę porównawczą dwóch modeli wyjaśniających 
podziały społeczne w realnym socjalizmie: ten zaproponowany przez Djilasa i Voslenskiego nazywa marksistowskim, a ten autorstwa Nowaka neo-weberowskim (Brzechczyn 28). Fakt, iż autorzy tych idei pochodzą z innych państw, wydaje się nie wystarczać do spełnienia przesłanki transnarodowości. Mamy zatem do czynienia z badaniem komparatystycznym, co zostaje dobitnie zobrazowane poprzez podsumowującą artykuł tabelę porównującą omawiane modele (Brzechczyn 39). Istotną zaletą artykułu jest wskazanie na zakres niedoborów konceptualizacyjnych odnośnie do podziałów społecznych w systemie demokracji ludowej. Jest to problem zdecydowanie ponadnarodowy i zmierzyć się z nim musi każdy badacz podejmujący szerszą refleksję nad dziejami komunizmu.

Artykuły pozostałych autorów rozpoczyna prezentacja terroru państwowego w radzieckiej Mołdawii w latach 1940-1989 pióra Igora Caşu. Jest to bardzo dobry artykuł, który angażuje czytelnika poprzez starannie dobrane przykłady konkretnych wydarzeń, jednocześnie prezentując wiele odniesień do statystyk z całego Związku Radzieckiego (Caşu 54). Ostatecznie jednak jest to udana realizacja programu historii porównawczej raczej niż transnarodowej. Sarolta Klenjánszky usiłuje zbliżyć się do tej drugiej, prezentując skomplikowane relacje między elitami partii komunistycznych w Moskwie, Budapeszcie i Paryżu po interwencji w Czechosłowacji. Pomimo zapowiedzi nowatorskiego, pluralistycznego spojrzenia czytelnik otrzymuje dość tradycyjną, choć wciągającą i poruszającą mało znany temat narrację o próbie realizacji własnych interesów przez Jánosa Kádára poprzez mediację między Moskwą i Paryżem. Mocnym punktem pracy jest niewątpliwie bogata baza archiwalna oraz przeprowadzone wywiady (Klenjánszky 87).

W części pierwszej najbliżej do podejścia transnarodowego zbliżył się Jens Boysen, opisując międzynarodowe aspiracje kadry dowódczej Paktu Warszawskiego. Zaletą tego artykułu jest sproblematyzowanie tradycyjnego napięcia między ideologią narodową i transnarodową, a w szczególności ukazanie jego dynamiki w bloku sowieckim (Boysen 57-58). W tym kontekście stawia autor pytanie o ewentualne możliwości badania Paktu Warszawskiego w kategoriach trans- lub ponadnarodowych (autor artykułu nie rozgranicza ostro tych pojęć, choć opisuje je jako narzędzia konceptualizacyjnes). W jego opinii jest to ciekawy trop, pomimo że naciąga on współczesne zachodnie pojęcie transnarodowości

5 Dokładne rozróżnienie między podejściem transnarodowym oraz ponadnarodowym niestety nie znalazło jeszcze uznania nie tylko wśród historyków, o czym wspominałem wcześniej, ale także wśród przedstawicieli innych nauk. Wydaje się, że powoduje to niepotrzebne zamieszanie. Zob. w politologii Rothert, Wierzchowska oraz w ekonomii Rosińska-Bukowska, Bukowski. 
do obcej mu sfery. Ostatecznie stwierdza Boysen, że w Pakcie Warszawskim transnarodowe były raczej personalne relacje najwyższego dowództwa wojskowego niż mechanizmy i procedury instytucjonalne. Autor sam zwraca uwage, że to nawet ograniczone zastosowanie odwraca nieco tradycyjny porządek narracyjny, w którym transnarodowość przypisywana była tylko elitom opozycyjnym na emigracji, a nie elitom wojskowym działającym w sercu sowieckiego imperium. Wiązać to należy z profesjonalizacją kadry oficerskiej, która musiała dostosować się do wymagań globalnego konfliktu jednocześnie odnajdując rozszerzoną poza granice kraju sferę swojej zawodowej działalności.

Rozdział drugi poświęcony ideologii teoretycznie najłatwiej powinien wpasowywać się w model „zawieszający” istnienie granic narodowych, szczególnie biorąc pod uwagę fakt, że ideologia komunistyczna była oparta na niezwykle uniwersalnych założeniach. Niestety, ważny metodologicznie dla dyskusji nad totalitaryzmem tekst Uwe Backesa poświęcony ewolucji i użyteczności pojęcia ideokracji jest na tyle ogólny, że w istocie ciężko odnieść go do jakiegokolwiek modelu narodowego, podczas gdy tekst Viliusa Ivanauskasa obrazuje funkcjonowanie sowieckiego etnofederalizmu na interesującym, ale dość specyficznym materiale litewskim. Teksty te pokazują, jak trudne jest zachowanie niezbędnej dla badań transnarodowych relacji między tym, co lokalne, i tym, co uniwersalne. $\mathrm{Z}$ drugiej strony wskazują one również na ciekawe sfery zastosowania konceptualizacji wypracowanych w tym modelu dla badań nad historią idei i historią kultury. Backes pokazuje potencjał konceptualizacyjny pojęcia ideokracji, które nie powinno być utożsamiane $z$ totalitaryzmem, i postuluje potencjalną jego użyteczność w nowszych badaniach porównawczych nad wydarzeniami w Iranie czy Syrii (Backes 127).

Ivanauskas opisuje natomiast drogę intelektualistów, którzy z pozycji komunistycznych przechodzili stopniowo na pozycje narodowe. Zestawia on napięcie między propagandą komunistyczną a narodową i wskazuje miejsca, gdzie te dwie łączyły się w takich konceptach jak „literatura tytularna” czy „przyjaciel narodu”. Niestety te elementy nie zostały mocniej wyeksponowane, a koncepcja etnofederalizmu rozpływa się w detalicznych analizach twórczości, dzienników, listów i notatek prasowych dotyczących dwóch ważnych pisarzy litewskich: Eduardasa Mieželaitisa i Justinasa Marcinkevičiusa (Ivanauskas 138-140).

Ten rozdział zamyka artykuł Évy Petrás o elementach romantycznych na Węgrzech pod koniec komunizmu. Najważniejszą tezą autorki jest próba odrzucenia tradycyjnej wizji powrotu do nacjonalizmu po erze uniwersalistycznych wpływów sowieckich. Ta wpływowa hipoteza kontynuacji tendencji nacjonalistycznych, które zostały jedynie zahamowane przez sowiecki imperializm, określana jest jako fridge-effect metaphor. W komunizmie nie można, zdaniem 
autorki, upatrywać antytezy nacjonalizmu i nie można postrzegać go głównie jako doktryny zastępującej przestarzałe podziały narodowe przez bardziej uniwersalne podziały klasowe. Jako argument podaje ona powrót romantyczno-narodowych historiografii po okresie ich relegowania przez centrum z Moskwy (Petrás 162). Niestety tym ciekawym uwagom brakuje szerszych konkluzji oraz wskazania na ewentualne związki między różnymi historiografiami Europy Środkowo-Wschodniej.

Dość niespodziewanie trzecia część książki poświęcona aspektom ekonomiczno-społecznym wydaje się najlepiej prezentować „nowe perspektywy”. Duża w tym zasługa świetnego ułożenia tekstów przez redaktora, ale również wyczucia metodologicznego poszczególnych autorów. Elitza Stanoeva już we wstępie twierdzi, że jej badania mogą przyczynić się do rozwoju podejścia transnarodowego stanowiącego dla niej uzupełnienie kontekstu międzynarodowego. W jej ocenie od około dekady można zaobserwować zwiększone zainteresowanie sowietologów problematyką konsumpcji. Autorka traktuje to jako część zwrotu kulturowego, zauważając, że badania te skupiały się dotychczas na handlu luksusowymi towarami i dopiero ostatnio modnym tematem stała się konsumpcja masowa jako efekt destalinizacji (Stanoeva 172). Bardzo dobry artykuł ukazuje faktyczne mechanizmy konsumpcyjne na przykładzie Bułgarii, rozszerzając wnioski na cały blok wschodni. Autorka w swoim case study (strategie sprzedaży w Centralnym Domu Towarowym w Sofii) pokazuje, jak propaganda naginała rzeczywistość, gdy tymczasem wymogi ekonomiczno-społeczne skłaniały władze do adopcji pewnych rozwiązań zachodnich, oferując elementy dobrobytu dla robotników.

Dobrym uzupełnieniem tych rozważań jest artykuł o konsumeryzmie w Rumunii. Mara Marginean również stwierdza, że dla analiz konsumeryzmu podejście transnarodowe jest w istocie konieczne. Autorka proponuje równie ciekawe studium przypadku, opisując hutę stali w Hunedoarze jako wzorcowy przykład sterowania obywatelem poprzez zaopatrzenie w produkty (Marginean 201). Wyjątkowa pozycja tej huty w Rumunii sprawiła, że zdecydowano się na skomplikowane badania statystyczne w celu znalezienia sposobu na optymalizację produkcji poprzez zmianę codziennego życia robotników. Autorka skupia się na wskazaniu dążeń do optymalizacji produkcji w oparciu o dane statystyczne i socjotechniczne mechanizmy kontroli. Niestety ten obiecujący i w wielu miejscach ciekawy artykuł pozbawiony jest klarownych wniosków, szczególnie pomijając kontekst transnarodowy.

Bardzo ciekawe podejście zaproponował Jakub Muchowski, który pokusił się o przeformułowanie swoich pytań badawczych z tej właśnie perspektywy. Metoda pracy skupiająca się na problemie autorealizacji w społeczeństwie 
PRL-u na przykładzie intymnych historii wysyłanych dla ilustrowanego tygodnika wydaje się bardzo obiecująca. Autor zauważa, że emocje są niezwykle uniwersalną wartością, która przebija się na powierzchnię w każdym społeczeństwie, oraz że samorealizacja, stanowiąca jeden z kluczowych konceptów liberalnego kapitalizmu, nie była bynajmniej obca społeczeństwom krajów komunistycznych. Artykuł trafnie podsumowuje ten niezwykle interesujący rozdział opisujący emocjonalne i społeczne skutki wprowadzania konsumeryzmu w krajach demokracji ludowej od lat pięćdziesiątych (Muchowski 230).

Czwarta część książki oferuje dość różnorodne propozycje, które łączyć ma właśnie perspektywa transnarodowa. Christie Miedema opisuje związki między aktywistami antywojennymi i rozbrojeniowymi w Polsce i Europie Zachodniej, co od samego początku jest założeniem transnarodowym. Autorka ewidentnie zdawała sobie sprawę, że ten temat badań skłania automatycznie do przyjęcia takiej perspektywy, i jako jedna $\mathrm{z}$ nielicznych pokusiła się o doprecyzowanie swojego rozumienia histoire croisée, zwracając uwagę na zainteresowanie oddolnymi związkami między wschodem a zachodem raczej niż odgórnie sterowanymi kontaktami dyplomatycznymi, charakterystycznymi dla tradycyjnego podejścia (Miedema 241). Pomimo próby konceptualizacji w istocie czytelnik otrzymuje dość tradycyjną narrację o kontaktach międzypaństwowych, prowadzonych jednak przez opozycjonistów, aktywistów i organizacje pozarządowe. Autorka właśnie w skupieniu uwagi na kontaktach pozarządowych widzi rolę nowych badań nad społeczeństwem. Najwięcej miejsca poświęca różnicom ideologicznym, które miały utrudniać bezpośrednie kontakty wybranych aktywistów. Fascynująca i nieznana kwestia, ale dość wybiórcza i o całym społeczeństwie mówi niewiele. Niemniej jednak jest to interesujący przyczynek do możliwego rozumienia tego, czym może być perspektywa transnarodowa i jak realizować ją w praktyce.

Pozostałe dwa artykuły w mniejszym stopniu wnoszą coś nowego do kwestii histoire croisée 6 . Jure Ramšak postuluje konieczność badań nad marksizmem właśnie z tej perspektywy, sam jednak nie spełnia tego postulatu w swojej analizie koncepcji słoweńskiej Nowej Lewicy (Ramšak 273). Dirk Mathias Dalberg przedstawia koncepcję samoorganizacji, którą w Polsce propagowali Jacek Kuroń i Karol Modzelewski w swoim „liście otwartym” z 1965 roku. Autor jednak nie skupia się na ewentualnych podobieństwach, różnicach lub kontaktach międzynarodowych, oferując wyłącznie analizę tej koncepcji w wydaniu czechosłowackiego dysydenta - Petra Uhla (Dalberg 316-317).

6 O konceptualizacji takiego podejścia zob. artykuł Michaela Wernera i Bénédicte Zimmermann, który polemizuje z wcześniej wspominanym tekstem Kocki, publikowanym również na łamach History and Theory (Werner, Zimmermann). 
Część piąta i ostatnia skupia się na kwestii pamięci i budowania narracji historycznych blisko moskiewskiego centrum ideologicznego. Dorota Malczewska-Pawelec i Tomasz Pawelec twierdzą, że niedostateczny jest nasz poziom wyjaśnienia socjalizmu w krajach Europy Środkowo-Wschodniej i za ten fakt odpowiedzialny jest przede wszystkim brak teoretycznych modeli adekwatnych dla tego specyficznego zadania (Malczewska-Pawelec, Pawelec 237-238). Autorzy zwracają uwagę na konieczność badań nad pamięcią historyczną w perspektywie porównawczej i transnarodowej, nie przeciwstawiając ich sobie. Proponują uznać za badania ponadnarodowe wszystkie te, które zmierzają do przełamania monopolu narracyjnego w kategoriach państwa narodowego i etnocentryzmu. Uznają zatem zróżnicowanie tego podejścia i definiują je w sensie negatywnym jako przełamywanie paradygmatu państwa narodowego (również powołując się na koncepcję Iordachiego i Apora).

Jako niezwykle interesujące pole eksploracji dla tak określonych nowych perspektyw wskazują autorzy politykę pamięci, podkreślając jednak szereg trudności, jaki jest z tym związany. Szczególnie problematyczne jest ustalenie i ocena narodowych narracji pamięci, które były przecież wypadkową dążeń społeczeństwa oraz rozgrywek między centralą w Moskwie i lokalnymi elitami. Zależność od jednego ośrodka decyzyjnego kierującego się jedną ideologia pozwala szukać w tej zróżnicowanej mozaice stałych mechanizmów. W tym sensie podejście komparatystyczne i transnarodowe wydaje się bardzo uzasadnione. Autorzy proponują przeprowadzić je systemowo poprzez ankietę społeczną bazującą na dwóch zestawach pytań: tym samym zestawie pytań dla wszystkich państw oraz na drugim zestawie pytań charakterystycznym dla konkretnego kraju. Takie rozdwojenie kwestionariusza pozwoliłoby zadowolić roszczenie do uznania wyjątkowości sytuacji konkretnych państw przy jednoczesnym poszukiwaniu wspólnych elementów polityki pamięci (Malczewska-Pawelec, Pawelec 232). Jest to zarys pewnych pomysłów oraz perspektyw badawczych (porównawczych raczej niż transnarodowych), który stanowi dobre wprowadzenie dla kolejnych dwóch artykułów prezentujących białoruskie i ukraińskie studia przypadku.

Największą wartością dwóch ostatnich tekstów w tym tomie jest to, że ukazują one „żywą aktualność” walki o politykę pamięci w byłych republikach radzieckich. Szczególnie ostatni artykuł jest niezwykle aktualny wobec napiętej sytuacji politycznej w rejonie Donbasu oraz najnowszych wypowiedzi historycznych prezydenta Putina. Zdumiewające, że został napisany jeszcze przed rewolucją Euromajdanu. Oleksii Polegkyij w swoim tekście podkreślił nieadekwatność perspektywy narodowej dla badań nad pamięcią historyczną na Ukrainie ze względu na mocny podział ideologiczny wewnątrz kraju (Polegkyi 363). 
Oznacza to, że istnieje wiele ważnych tematów badawczych, których nie sposób adekwatnie opisać bez zastosowania sugerowanych "nowych perspektyw”. Ta w istocie smutna konstatacja na zakończenie książki może stanowić wyzwanie dla nowej generacji badaczy.

W podobnie pesymistycznym tonie kończy swój świetny artykuł Anna Zadora, konstatując, że polityka historyczna oparta na wojnach i tragediach jest zwykle nietrwała, szczególnie jeśli nie dopuszcza wolnej dyskusji z innymi narracjami. Pokazała to chociażby odwilż lat osiemdziesiątych i sprawa Kuropat. W tym sensie niestety prowadzi to do stwierdzenia, że aktualna tożsamość narodowa na Białorusi nie jest trwała. Perspektywa transnarodowa wydaje się zatem trudna do wprowadzenia na Białorusi, gdzie istnieje klarowny podział na „naszą” (tzn. rosyjską i białoruską) narrację zwycięstwa oraz „obcą” (tzn. zachodnią i europejską) narrację humanitarną o tragedii (Zadora 354).

Reasumując, należy stwierdzić, że większość tekstów, włączając w to sam tekst Krzysztofa Brzechczyna, nie oddziela w praktyce badań transnarodowych od porównawczych. Fakt, że większość Autorów stosuje metodę porównawczą, pokazuje paradoksalnie nie tylko przydatność tej książki, ale wręcz jej niezwykłą aktualność. Nie jest to pozycja wyczerpująca temat, ale tak też nie powinno się dziać przy wytyczaniu nowych perspektyw. Pokazuje ona zarówno teoretycznie, jak i praktycznie, że wiele jeszcze pozostaje do zrobienia, aby można było określić perspektywę transnarodową jako dokładnie zestandaryzowaną i ugruntowaną (a w konsekwencji już „nienową”). W praktyce ostre rozgraniczenie między historią porównawczą a transnarodową jest bardzo trudne, co rodzi pytanie, czy w istocie jest ono zasadne.

W tym względzie rozdział trzeci poświęcony konsumeryzmowi napawa optymizmem, udowadniając, że takie badania są jednak możliwe, a często wręcz konieczne dla zrozumienia pewnych procesów (np. konsumeryzmu sowieckiego). Wynika to również z rozdziału piątego, który nie tylko szkicuje ambitne plany dalszych prac nad perspektywą transnarodową w historiografii, ale wskazuje dobitnie, jak bardzo aktualne jest to zadanie, które nie dzieje się jednak w politycznej próżni. Historiografia Europy Środkowo-Wschodniej pozostaje nie mniej skomplikowana niż jej historia. Tym bardziej należy z uznaniem powitać ukazanie się tej publikacji, która pokazuje niezwykle szerokie spektrum problemów teoretycznych i praktycznych stojących przed kolejnymi generacjami badaczy. Pytaniem, które nie zostało jednoznacznie wyjaśnione, pozostaje wzajemna relacja perspektywy transnarodowej oraz komparatystycznej w tych badaniach. Niewątpliwe jest jednak to, że ta dyskusja trwa, a Krzysztof Brzechczyn wraz z gronem współautorów zabrał w niej ważny głos. 


\section{| Bibliografia}

Apor Peter, Iordachi Constantin. "Introduction, Studying Communist Dictatorships: From Comparative to Transnational History". East Central Europe 40 (2013). S. 1-35.

Backes, Uwe. "Decadent Ideocracies? Specifics and Changes of Regime Legitimation in Real Socialist Countries". New Perspectives in Transnational History of Communism in East Central Europe. Red. K. Brzechczyn. Bern: Peter Lang, 2019. S. 101-136.

Bayly C.A., et al. “AHR Conversation: On Transnational History”. The American Historical Review 111/5 (December 2006). S. 1441-1464.

Boysen, Jens. "Integration through „Militarism” in the Warsaw Pact: The East German and Polish Leaderships as Soviet Allies". New Perspectives in Transnational History of Communism in East Central Europe. Red. K. Brzechczyn. Bern: Peter Lang, 2019. S. 57-76.

Brzechczyn, Krzysztof. "Between Modernization and Enslavement: The Historiosophical Implications of Two Approaches to the Social Divisions in Real Socialism". New Perspectives in Transnational History of Communism in East Central Europe. Red. K. Brzechczyn. Bern: Peter Lang, 2019. S. 25-42.

Brzechczyn, Krzysztof. "The Transnational Perspective in Research on Communism: Foreword”. New Perspectives in Transnational History of Communism in East Central Europe. Red. K. Brzechczyn. Bern: Peter Lang, 2019. S. 15-21.

Cașu, Igor. "State Terror in Soviet Moldavia, 1940-1989: Categories of Victims, Repressive Methods and Punitive Institutions". New Perspectives in Transnational History of Communism in East Central Europe. Red. K. Brzechczyn. Bern: Peter Lang, 2019. S. 43-56.

Dalberg, Dirk Mathias. “The 'Program of Society's Self-Organization' The Political Thinking of Petr Uhl”. New Perspectives in Transnational History of Communism in East Central Europe. Red. K. Brzechczyn. Bern: Peter Lang, 2019. S. 293-323.

Friedrich Carl. J., red. Totalitaryzm. Materiały z konferencji zorganizowanej przez Amerykańska Akademię Sztuk i Nauk w marcu 1953 roku. Przeł. Sebastian Szymański. Warszawa: Instytut Pileckiego, 2019.

Iriye, Akira. Global and Transnational History: The Past, Present, and Future. London: Palgrave Pivot, 2013.

Ivanauskas, Vilius. "Lithuanian Soviet Writers and «Titular Literature»: Three Generations in a Changing Environment". New Perspectives in Transnational History of Communism in East Central Europe. Red. K. Brzechczyn. Bern: Peter Lang, 2019. S. 137-156. 
Klenjánszky, Sarolta. "Entangled Histories of the Hungarian Socialist Workers' Party and the French Communist Party after the Invasion of Czechoslovakia”. New Perspectives in Transnational History of Communism in East Central Europe. Red. K. Brzechczyn. Bern: Peter Lang, 2019. S. 77-98.

Kocka, Jürgen. "Comparison and Beyond". History and Theory 42/1 (2003). S. 39-44.

Kocka Jürgen, Haupt Heinz-Gerhard. "Comparison and Beyond. Traditions, Scope and Perspectives of Comparative History". Comparative and Transnational History: Central European Approaches and New Perspectives. Red. J. Kocka, H-G. Haupt. New York-Oxford: Berghahn, 2009. S. 1-30.

Lóránd, Zsófia. „Idee nowego feminizmu: stawianie państwu wyzwań czy udoskonalanie jugosłowiańskiego socjalizmu?". Nowe perspektywy badawcze $w$ transnarodowej historii komunizmu w Europie Środkowo-Wschodniej. Red. K. Brzechczyn. Poznań-Warszawa: IPN, 2019. S. 239-250.

Malczewska-Pawelec Dorota, Pawelec Tomasz. "A Study of Memory Politics as a Research Program for a Transnational History of Communism in East-Central Europe. New Perspectives in Transnational History of Communism in East Central Europe. Red. K. Brzechczyn. Bern: Peter Lang, 2019. S. 327-340.

Marginean, Mara. "Mis/Managing Industrial Labour Productivity by the Late 1950s: Work, Collective Consumption, and Technologies of Nation Building in Romania”. New Perspectives in Transnational History of Communism in East Central Europe. Red. K. Brzechczyn. Bern: Peter Lang, 2019. S. 199-220.

Miedema, Christie. "A Transnational Movement Breaking Down the Blocs? The "Alliance» Between the Western Peace Movement and the Polish Opposition in the 1980s". New Perspectives in Transnational History of Communism in East Central Europe. Red. K. Brzechczyn. Bern: Peter Lang, 2019. S. 239-269.

Muchowski, Jakub. "Intimacies under State Socialism? Poles Emotional Self-Realization in the 1960s". New Perspectives in Transnational History of Communism in East Central Europe. Red. K. Brzechczyn. Bern: Peter Lang, 2019. S. 221-235.

Petrás, Eva. "Prevailing Romantic Elements of Hungarian Nationalism at the End of the Socialist Era - Their Origin and Influence on Nationalism". New Perspectives in Transnational History of Communism in East Central Europe. Red. K. Brzechczyn. Bern: Peter Lang, 2019. S. 159-169.

Polegkyi, Oleksii. "Russian and Ukrainian Struggles over 'Historical Narratives': Post-Imperial versus Post-Colonial Perspectives". New Perspectives in Transnational History of Communism in East Central Europe. Red. K. Brzechczyn. Bern: Peter Lang, 2019. S. 359-372. 
Radeljić, Bronislav. „Stosunki między Wspólnotą Europejską a Jugosławią: dokumenty, które miały znaczenie (1980-1992)". Nowe perspektywy badawcze $w$ transnarodowej historii komunizmu $w$ Europie Środkowo-Wschodniej. Red. K. Brzechczyn. Poznań-Warszawa: IPN, 2019. S. 251-266.

Ramšak, Jure. "'Consumption of Revolutionary Ideas': New Left and Student Criticism in Slovenia 1971-1974”. New Perspectives in Transnational History of Communism in East Central Europe. Red. K. Brzechczyn. Bern: Peter Lang, 2019. S. 271-292.

Rosińska-Bukowska Magdalena, Bukowski Józef. „Transnarodowość - zjawisko determinujące kształt współczesnej gospodarki światowej”. Studia Ekonomiczne 266 (2016). S. 61-70.

Rothert Agnieszka, Wierzchowska Anna, red. Rządzenie w przestrzeni ponadnarodowej. Studia Politologiczne Tom 27. Warszawa: Instytut Nauk Politycznych Uniwersytetu Warszawskiego, 2013.

Stanoeva, Elitza. "Inventing the Socialist Consumer: Worker, Citizen or Customer? Politics of Mass Consumption in Bulgaria, 1956-1968". New Perspectives in Transnational History of Communism in East Central Europe. Red. K. Brzechczyn. Bern: Peter Lang, 2019. S. 171-198.

Tucker, Robert C. "On the Comparative Study of Communism". World Politics 19/2 (1967). S. 242-257.

Werner Michael, Zimmermann Bénédicte. "Beyond Comparison: Histoire Croisée and the Challenge of Reflexivity". History and Theory 45(1) (2006). S. 30-50.

Zadora, Anna. “The Second World War in Belarus: A Fundamental Event for National Building and International Relations". New Perspectives in Transnational History of Communism in East Central Europe. Red. K. Brzechczyn. Bern: Peter Lang, 2019. S. 341-358.

\section{| Nota o autorze}

Piotr Kowalewski - dr, adiunkt w Instytucie Historii Uniwersytetu Śląskiego. Magister filozofii, historii oraz prawa. Doktor nauk społecznych w specjalizacji historia na podstawie pracy Tradycja i aktualność analitycznej filozofii historii. Przypadek Arthura C. Danto (przygotowywana do druku). Zainteresowania badawcze koncentruje wokół współczesnej teorii humanistyki w nauce, literaturze i sztukach wizualnych. Prowadzi również badania z zakresu historii i teorii prawa systemów totalitarnych oraz historii historiografii.

E-mail: piotr.kowalewski@us.edu.pl 